\title{
LAS PIONERAS
}

\section{UN REPORTAJE PARA ELLAS}

The pioneer women. A reportage to them

\section{Elsa Estremadoyro}

Fotógrafa e investigadora

Asociación de Fotoperiodistas del Perú - AFPP. elsaestrema@gmail.com

\section{RESUMEN}

A poco de cumplirse cincuenta años de la publicación de la primera fotografía realizada por una mujer en un medio de prensa peruano, dentro de un contexto de reconocimiento hacia el rol de la mujer en todos sus ámbitos, la fotografía de prensa en el Perú tiene historias que contar. Las mujeres que integran la primera generación de fotoperiodistas peruanas, se encontraban más cerca de lo que imaginamos. Este texto recoge las voces y los testimonios de once pioneras y los caminos que recorrieron.

\section{ABSTRACT}

Shortly after the fiftieth anniversary of the publication of the first photograph taken by a woman in a Peruvian press, within a context of recognition of the role of women in all areas, press photography in Peru has stories to tell. The women who make up the first generation of Peruvian photojournalists were closer than we imagine. This text collects the voices and testimonies of eleven pioneers and the paths they traveled.
Female photographers, Peruvian history, press. currió durante la revolucionaria década de setenta. Una tras otra, fueron llegando, cámara en mano, las que forjarían el camino -que hasta ese momento era territorio exclusivo del reportero gráfico-a punta de fortaleza. Fue definitivo, la calle empezó a cubrirse de disparos femeninos.

Ser autodidactas y madres de familia no detuvo a las dos mujeres que inician esta historia en épocas -a las que llamaremos arcaicas- de rollos de película, revelados en laboratorio y cámaras analógicas. Las cuales eran las herramientas indispensables ya que ni por asomo nos imaginábamos la revolución digital que transformaría a la fotografía de prensa años más tarde.

En 1972, cuando una empeñosa Alicia Benavides publicó su primera fotografía en la sección de culturales de la revista Oiga, no imaginó que estaba marcando un hito. El país se encontraba pasando por tiempos agitados y no mucho después la censura cerró Oiga. Alicia pasó a colaborar con la revista Caretas donde su trabajo puntilloso gustaba y sus retratos destacaban. Benavides construyó un importante archivo poblado de personajes destacados en el mundo del arte: Ribeyro, Szyszlo, Vargas Llosa, Varela, Tilsa figuran entre los mas renombrados.

Apasionada por la noticia, no dudó en embarcarse en nuevos retos, como cuando fue comisionada para cubrir una huelga de hambre que hicieron algunos periodistas para frenar las amenazas de cierre de los medios de comunicación, durante el gobierno militar de Morales Bermúdez. La reportera llegó con su frazada preparada para unirse al grupo de protesta, ueron siete días en los que los periodistas, de izquierda y derecha, compartieron espacio en un salón donde durmieron sobre dos colchones, uno para cada bando. "A pesar de las diferencias de ideas, por las noches conversábamos y discutíamos entre todos muy alturadamente". La huelga fue estricta, durante ese tiempo, la fotógrafa y su equipo sólo bebieron agua de boldo que les llevaba Doris Gibson, fundadora del semanario. "Teníamos una pancarta que decía : 14 periodistas en huelga de hambre por la libertad. El asunto era que mis padres lo veían todo por televisión, -pobre mi hija- suspiraba mi mamá. Ahora que pienso en ellos, me doy cuenta de que pagaban pato con mi trabajo." Afortunadamente al octavo día se llegó a buen acuerdo y se levantó la huelga. La Chichi, como la llaman con cariño, tiene en la actualidad 82 años, después de una carrera como maestra universitaria, presentó en 2019 una muestra retrospectiva en el Centro de la Imagen.

Un caluroso domingo de 1974, Beatriz Suárez regresaba de un almuerzo familiar cuando se encontró con un microbús que ardía. Como tenía su cámara en la cartera no dudó en bajarse del auto y acercarse a fotografiar las llamas. Tras el incendio, fue directo a casa para revelar su rollo $6 \times 6$ e hizo llegar las fotos a una amiga, quien trabajaba en el noticiero $E I$ Panamericano. Horas después, aparecieron en la pantalla las imágenes junto a la voz en off del narrador que decía "Ha nacido una fotógrafa" grande fue su sorpresa al darse cuenta de que la convirtieron en la protagonista de la noticia. Los medios de prensa se interesaron por el material y fue publicado al día siguiente, simultáneamente en las portadas de La Prensa, El Comercio y La Crónica. Su vida tomó un rumbo inesperado, se le abrieron las puertas para iniciar colaboraciones con el diario La Prensa.

En una carrera plena de matices y de perfil bajo, destaca su participación en los primeros movimientos feministas, en especial las colaboraciones que hizo con la revista Manuela del Centro Manuela Ramos, que incluía la publicación de fotonovelas en las que la fotografía 
era usada como herramienta de denuncia, abordando por primera vez temáticas sobre aborto, violencia de género y racismo en un medio impreso.

Posteriormente irrumpen en el medio "las chinas" Antonieta Gamarra y Carmen Barrantes, que se dedican a cubrir las violentas marchas a recibir más de un cachiporrazo de las fuerzas policiales, porque la represión en aquella época era tan o más agresiva que hoy.

Antonieta Gamarra, viuda del recordado Chino Domínguez, recuerda que afinó su ojo mientras observaba las fotografías de su esposo. Hasta el momento, ella es quien tiene la trayectoria más larga ya que admirablemente se mantuvo activa en el medio hasta las cercanías del año 2015. Fue parte del equipo fundador del diario La República y posteriormente trabajó para organismos estatales.

La "China" Barrantes fue una fotógrafa independiente con todas sus letras. Trabajaba para periódicos alternativos de izquierda y ella misma se hacía cargo de todo el proceso, tanto del revelado del material como de la distribución. Comenta que tenía una clientela "caserita" que la buscaba después de las marchas, para comprar sus fotos. Formó parte de INTERFOTO una agencia de prensa que reunió a un grupo de fotógrafos independientes con el fin de brindarse protección ante el alto riesgo que corrían en la calle. "En el momento que yo ejercí, ser reportero gráfico era considerado un oficio menor. No éramos considerados independientemente de que fueras buen o malo como fotógrafc ganábamos menos que los redactores. Eso era también porque no estábamos profesionalizados, había una discriminación hacia el oficio".

Alejada del periodismo, se dedicó a hacer trabajo social desde otras plataformas. Treinta años después, Barrantes vuelve a la fotografía para denunciar la minería ilegal. "Al agarrar la cámara me transformé. Me di cuenta de que nunca dejas de ser fotógrafa porque lo llevas en la sangre".

Muy cerca de ellas, Mariel Vidal tuvo que $7 ?$
Lima no existían escuelas para estudiar fotografía. A su regreso, en 1977, recibe la propuesta para trabajar en la agencia de noticias UPI posteriormente trabajaría para el mítico suplemento cultural El Caballo Rojo que dirigía Toño Cisneros. "En una ocasión salí a las afueras de Lima a cubrir una marcha de mujeres. La Policía me persiguió hasta mi auto y me detuvo, recuerdo que me hice la pila del miedo, me llevaron a la comisaría y me velaron los rollos, pero yo me había escondido dos entre mi ropa interio Cuando se es joven como que no se miden los riesgos. Afortunadamente mi jefe acudió rescatarme las fotos se publicaron al día siguiente y a míme mandaron dos semanas de vacaciones para protegerme."

A Vidal, el periodismo se le presentó de manera fortuita, ella es esencialmente fotó grafa y como tal formó parte de la Fotogalería Secuencia que fue la primera galería de arte dedicada a la fotografía en el Perú. Su serie "Costa" es uno de los primeros ensayos documentales que desarrolla el tema de la migración en Lima. Captura el relajo y el disfrute de los uviera conmigo." Actualmente vive en la ciudad de Toledo, pero no se ha desligado del Perú y mucho menos de la fotografía. Por donde va, siempre lleva la cámara en mano.

Hacia fines del setenta, María Cecilia Piazza se acerca al fotoperiodismo. Aunque su obra es reconocida sobre todo por su carácter artístico, Piazza mantiene un interés por cubrir los hechos noticiosos bajo sus propias claves. Mantiene cierta distancia de los hechos, los rodea, y esto e permite acentuar el lenguaje simbólico. Sus colaboraciones con la revista Quehacer, donde publicaba imágenes cargadas de claroscuros, fueron un aporte novedoso en aquel momento. Sus fotografías destacaron por el minucioso trabajo de laboratorio, ya que acostumbraba pasar horas en el cuarto oscuro hasta lograr la calidad que deseaba en sus imágenes. Esto hoy parece natural, sin embargo, para la época, la práctica del laboratorio era incipiente.

Al término de la década del ochenta Rocío Cáceres regresa al país luego de realizar estudios de fotografía en Londres e inicia colaboraciones en Testimonio, una revista que dirigía César Hildebrandt. Luego pasó a la revista Sí, donde tuvo la oportunidad de curtirse cubriendo los años más duros del período de violencia interna. Fue, propiamente dicho, una fotógrafa de guerra. "En Ayacucho bajé a los infiernos. La dinámica era que los periodistas salíamos a hacer los recorridos con un pelotón del Ejército, fuera de día o de noche, durante esos recorridos vi mucha muerte. Todo estaba envuelto en una violencia espantosa".

Un retrato que realizó durante la campaña electoral de 1990, al entonces candidato Alberto Fujimori, mostraba al futuro presidente vestido con una "bata" y una espada con un ligero tono o remedo del estilo samurái. La foto rebotó en medios internacionales, e incluso se publicó en diarios japoneses, lo que causó las iras del candidato, quien amenazó a la fotógrafa. Algunos años después Rocío decidió retirarse del trabajo periodístico, sin retorno.

Mónica Newton era una economista que no se hallaba a gusto con su profesión. Casada y con tres hijos, en 1984 se inscribió en un curso que dictaba el taller La Araña y fue en ese lugar que despierta su pasión por la fotografía. En un viaje al extranjero con su familia, ahonda en sus estudios y se interesa por el fotoperiodismo. A su regreso al país, inicia prácticas en el diario Ojo, en donde se convierte en la primera mujer en integrarse al equipo de reporteros gráficos. "Ojo fue una escuela para mi y Andrés Longh fue un súper guía. Me confió la misión de hace de la realidad algo menos trágica. Quería empezar desde abajo, desde lo más simple, pero durante los primeros meses enfrenté boicots de mis compañeros de trabajo. Me velaban los negativos, no me firmaban las buenas fotos, etc Al cabo de un tiempo fueron dándose cuenta de que yo realmente trabajaba y de que no era la 'pituquita' que ellos pensaban que era. Al cabo de seis meses me había ganado su respeto".

Posteriormente, Newton trabajaría para la Unidad de Investigación del diario La República dedicándose a cubrir temas sobre narcotráfico. La Amazonía la conectó con una vida que ella desconocía. "A pesar de la violencia que sufría el pueblo Ashaninka su vida cotidiana seguía un ritmo natural, ellos podían cambiar de cana en medio de escenarios dramáticos. Fotografiar ese momento en que la vida y la muerte hacen un contrapunto fue transformador para mí.

Muy cerca, Vera Lentz es la fotoperiodista que ha recibido mayor reconocimiento por su extraordinaria cobertura del conflicto armado interno entre 1980 y 2000. Su madre fue una retratista alemana que tuvo un concurrido estudio en Miraflores. Educada en el extranjero, cuando regresa al país durante los primeros años de la década del 80, Lentz fotografía, desde la primera línea, con el objetivo de documentar la crudeza del conflicto desde todos sus ángulos. Su obra se puede apreciar como parte de la muestra Yuyanapaq, de la CVR. Actualmente se dedica a la enseñanza universitaria.

Fátima López es, posiblemente, la primera alumna egresada de una facultad de comunicaciones que se forja como fotógrafa de prensa en el Perú. Lo que ocasionó reacciones adversas entre algunos reporteros gráficos de oficio, quienes se incomodaron por el hecho de que una mujer universitaria se desempeñara a la par que ellos. Tenaz y aguerrida, López supo defender su espacio sin ceder ante los agravios. Acostumbrada a darlo todo de sí durante las comisiones, no cejaba hasta lograr la foto que el editor esperaba. El otro lado de la moneda era que no medía el peligro de las condiciones en que se encontraban, la adrenalina superaba de largo al temor

Los fotógrafos trabajaban con su propio equipo, no tenían ningún tipo de seguro y el país estaba en guerra. "Vivía cerca de Tarata, cuando sentí la explosión tomé mi maletín y salí corriendo, cuando llegué al cruce de Benavides con Alcanfores me di cuenta de la magnitud del ataque y de lo que me esperaba. Pasé la noche allí, fue dantesco, nos trastornó a todos". La trayectoria de Fátima ha sido muy amplia, se inicia en 1988 en el suplemento VSD de La República, trabajó luego para la revista Caretas, el diario El Comercio, las revistas Quehacer y Debate. Actualmente vive fuera del Perú y continúa su labor como fotógrafa.

Este recuento no puede dejar de mencionar a Eva Castro, quien trabajó para la revista Sí. Cuando el candidato Fujimori fue electo 
presidente en 1990, ella fue contratada como fotógrafa exclusiva del Presidente y de su familia. Fue precisamente realizando un viaje con la comitiva presidencial que la camioneta en que se desplazaba sufrió un accidente en la carretera y Eva falleció. El rescate de su obra es aún una labor pendiente.

Al salir de la universidad, Nancy Chappell pensaba dedicarse al periodismo escrito. Pero mientras hacía prácticas en el diario Ojo se dio cuenta de que lo suyo era la cámara, y no se equivocó. "Sentía que las palabras me quedaban cortas". Una trayectoria de treinta y tres años y un recorrido por varios medios, entre los que recordamos el diario Página Libre y, más recientemente, el diario El Comercio, forman parte de su historia. "Hice mis prácticas de fotografía entre coches bomba y balas. Al inicio no era consciente de los riesgos, hasta que cubrí un atentado, donde un taxista minutos antes había muerto quemado por terroristas, ese día tuve miedo".

Paralelamente a su trabajo en medios, Nancy ha construido un trabajo entrañable, en el que destacamos su ensayo sobre la ciudad de el que destacamos su ensayo sobre la ciudad de un impecable manejo de la luz, su serie de fotografías nos muestra el fervor y la fortaleza de un pueblo que se recupera de sus dolores. "Llegar rostros de la gente, como limeñ, horizo los hizo sentir mal porque había vivido y visto todo el conflicto de una manera muy lejana. Estuve distanciada de mi profesión hasta que Mayu me propuso trabajar en el proyecto de la CVR". Actualmente, trabaja como fotógrafa independiente.

Fue en un curso universitario dictado por Jorge Deustua, que Mayu Mohanna decidió ser fotógrafa. Corrían los primeros días del verano de 1990, cuando empezó a trabajar para la revista Sí, estaba decidida a enfrentar la calle y a poner todo de su parte hasta lograr "la foto". La fotografía fue una prioridad para ella y ocupó gran parte de su tiempo por muchos años. Por ejemplo, para poder realizar su ensayo "Rituales", juntaba sus días libres y tomaba vacaciones por quincenas para poder viajar a cubrir las fiestas religiosas. Estos viajes signi- del país y retornar a sus orígenes, pues ella nació en Chimbote y migró a Lima para iniciar estudios universitarios.

Con el nuevo siglo, surgen también nuevos intereses dirigidos hacia la investigación de archivos fotográficos. El proyecto para poner en valor la obra del ayacuchano Baldomero Alejos, en el año 2000, lleva a Mayu a iniciar su camino como curadora y editora de fotografía. Trabajo que se consolida cuando recibe el encargo de la CVR para realizar la inmensa muestra Yuyanapaq. "Incluso ahora que estoy haciendo museografía, siento que estoy fotografiando. Porque cuando compongo de forma tridimensional en una sala, estoy editando e iluminando en la pared. Propiamente no hago fotos ahora, pero siento que sigo haciéndolas."

Si bien esta investigación abarca a las fotógrafas que surgieron durante el período de 1970 a 1990, es importante agregar que, en la última década del siglo XX, la presencia de un batallón de entusiastas reporteras se incrementó en los medios de prensa, gracias a que-por fin- las currículas universitarias incorporaron cursos de fotografía en las facultades de comunicación logrando que la labor del reportero gráfico se profesionalice y adquiera un nuevo 'estatus'.

El espacio queda corto para mencionar a todas las fotógrafas que destacaron en aquel tiempo. Como Silvia Izquierdo y su trabajo sobre el rescate de los rehenes de la embajada japonesa, en 1997; Verónica Salem y sus muchas imágenes que perduran nítidas en nuestra retina, como las manos negras de los Fujimori luego de trepar la reja de Palacio de Gobierno en el año 2000; Pilar Olivares y su infatigable caza de las mejores fotografías en las muchas coberturas futbolísticas; Úrsula Cáceres y la icónica imagen de una pequeña Sofía Mulánovich, de nueve años, abrazada de su tabla en la portada de Somos; y tantas otras que vinieron después, y que aún nos iluminan con la luz inacabable de sus fotografías. Hoy, los flashes son para ellas.

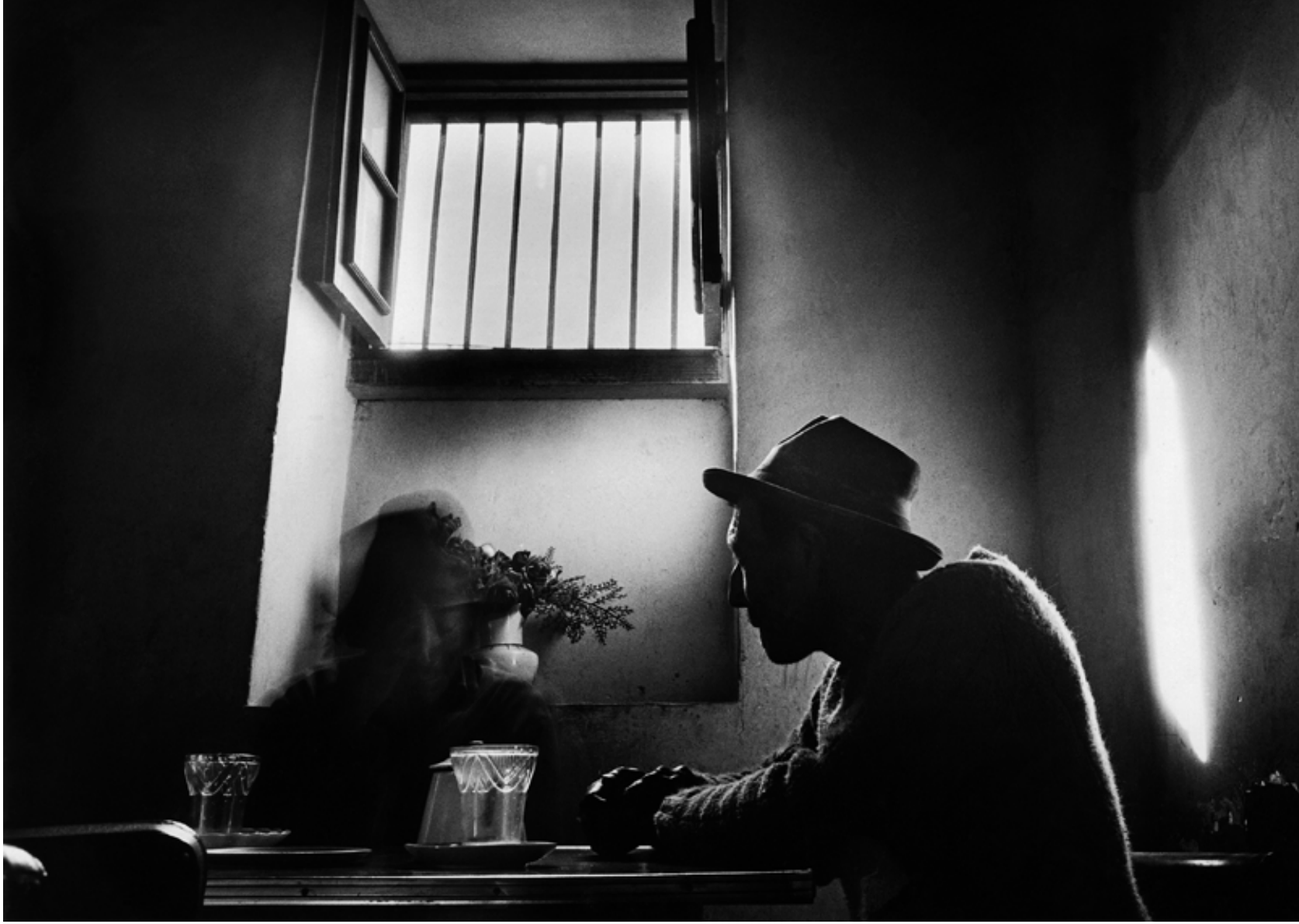

Conversación. Yauyos, 1980. Maria Cecilia Piazza.

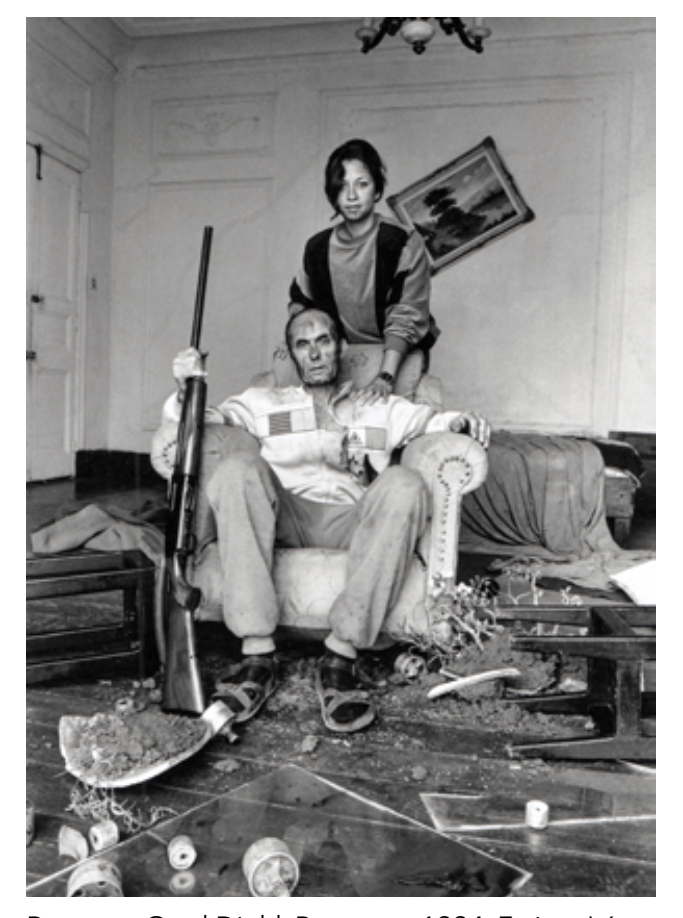

Retrato a Gerd Diehl. Barranco, 1994. Fatima López.
OTRAS FOTÓGRAFAS (1970-2000)

CHARLOTTE BURENIUS

ARMIDA TESTINO

FRANÇOISE SMET

ANA CECILIA GONZALES VIGIL

MARIANA BAZO

ROXANA ARTACHO

TATI QUIÑNONES

CECILIA LARRABURE

CONSUELO VARGAS

INÉS MENACHO

ALEJANDRA BRUN

SILVIA NEYRA

FLORA HARO

GUISELA CÁCERES

CECILIA DURAND

ELSA ESTREMADOYRO

JIMENA CORONADO

CARMEN RÁVAGO

FLOR SÁNCHEZ

MAGALÍ DEL SOLAR. 


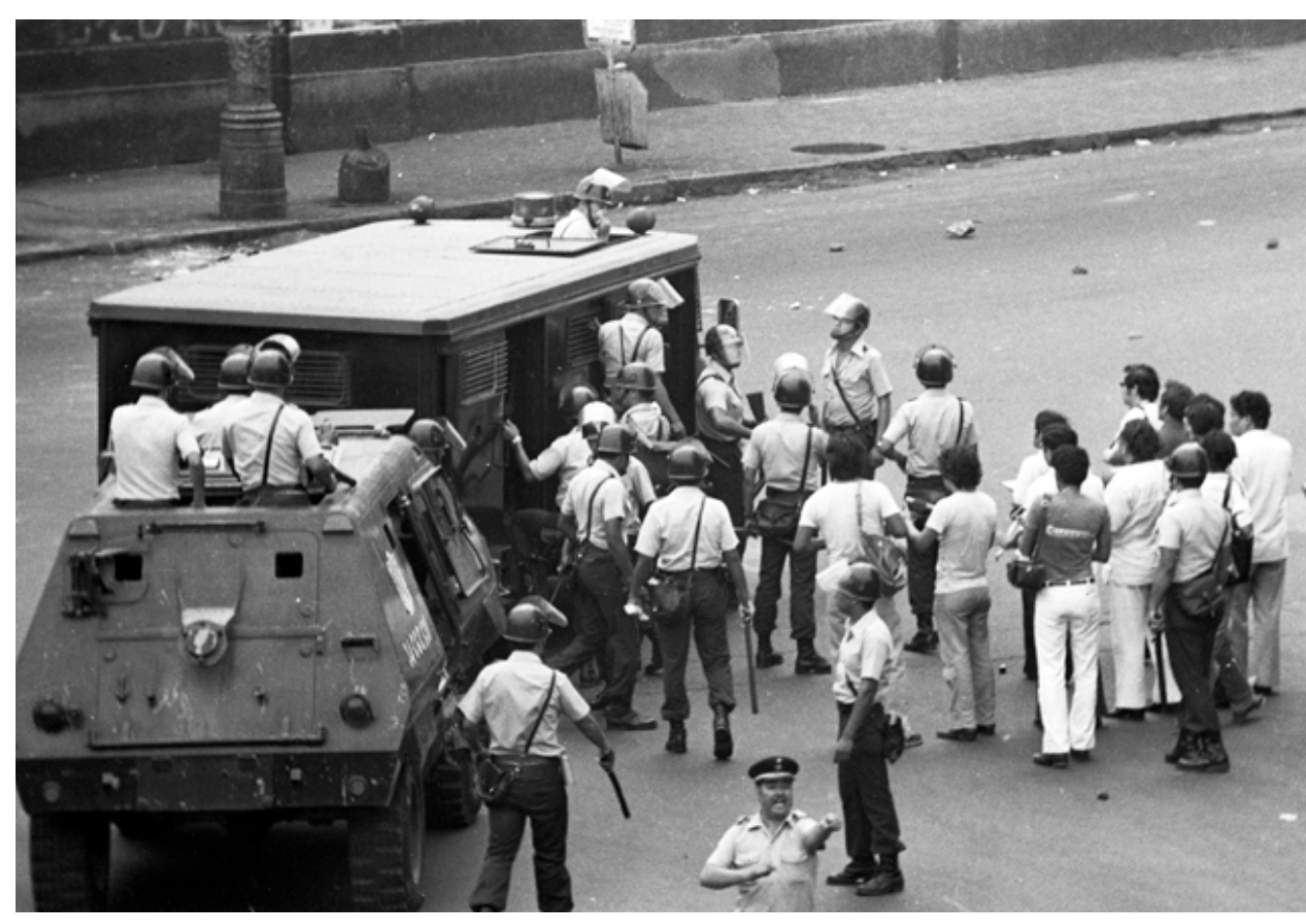

Paro nacional. Lima, 1977. Cármen Barrantes.

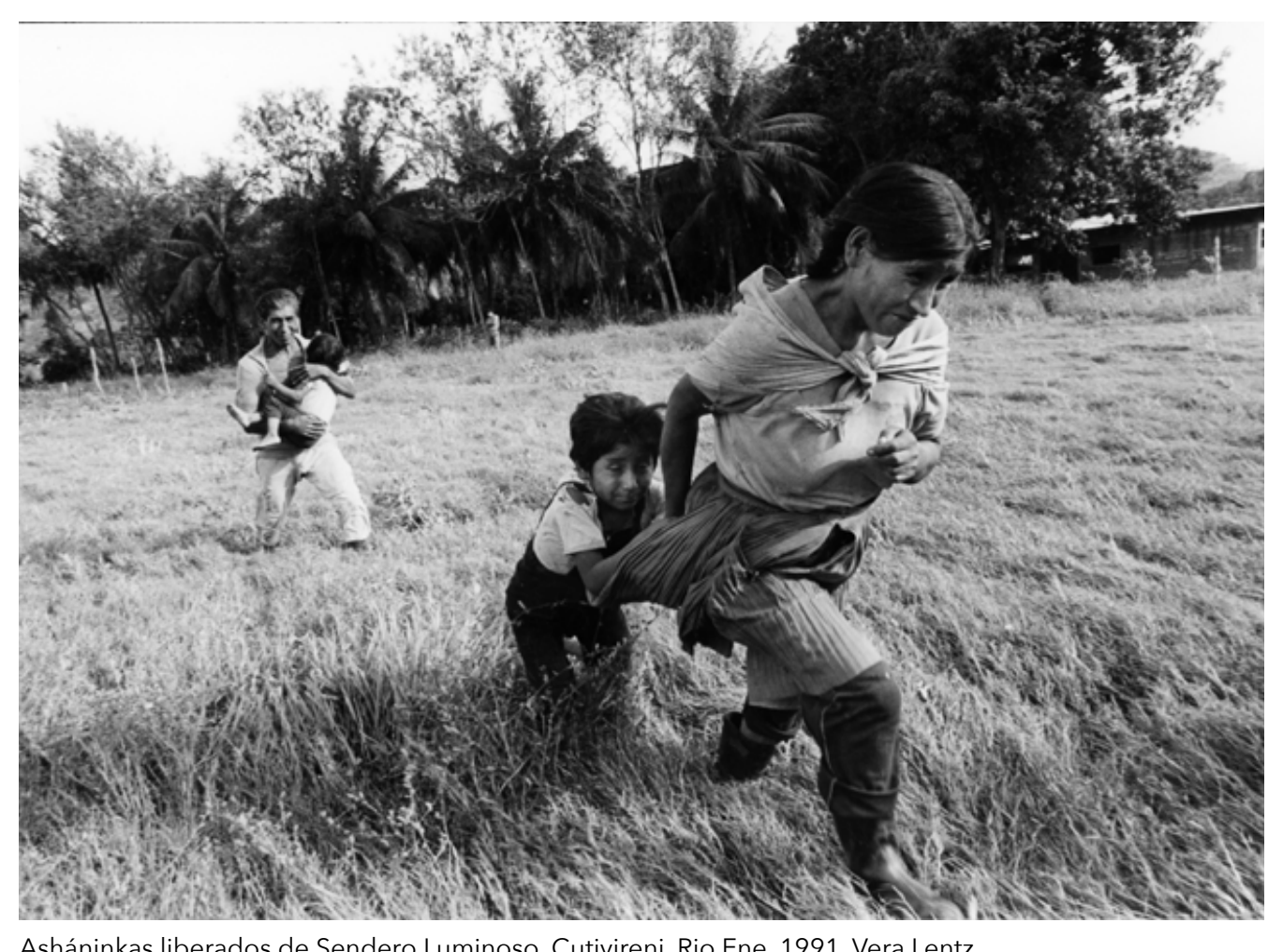
Asháninkas liberados de Sendero Luminoso. Cutivireni, Rio Ene, 1991. Vera Lentz.

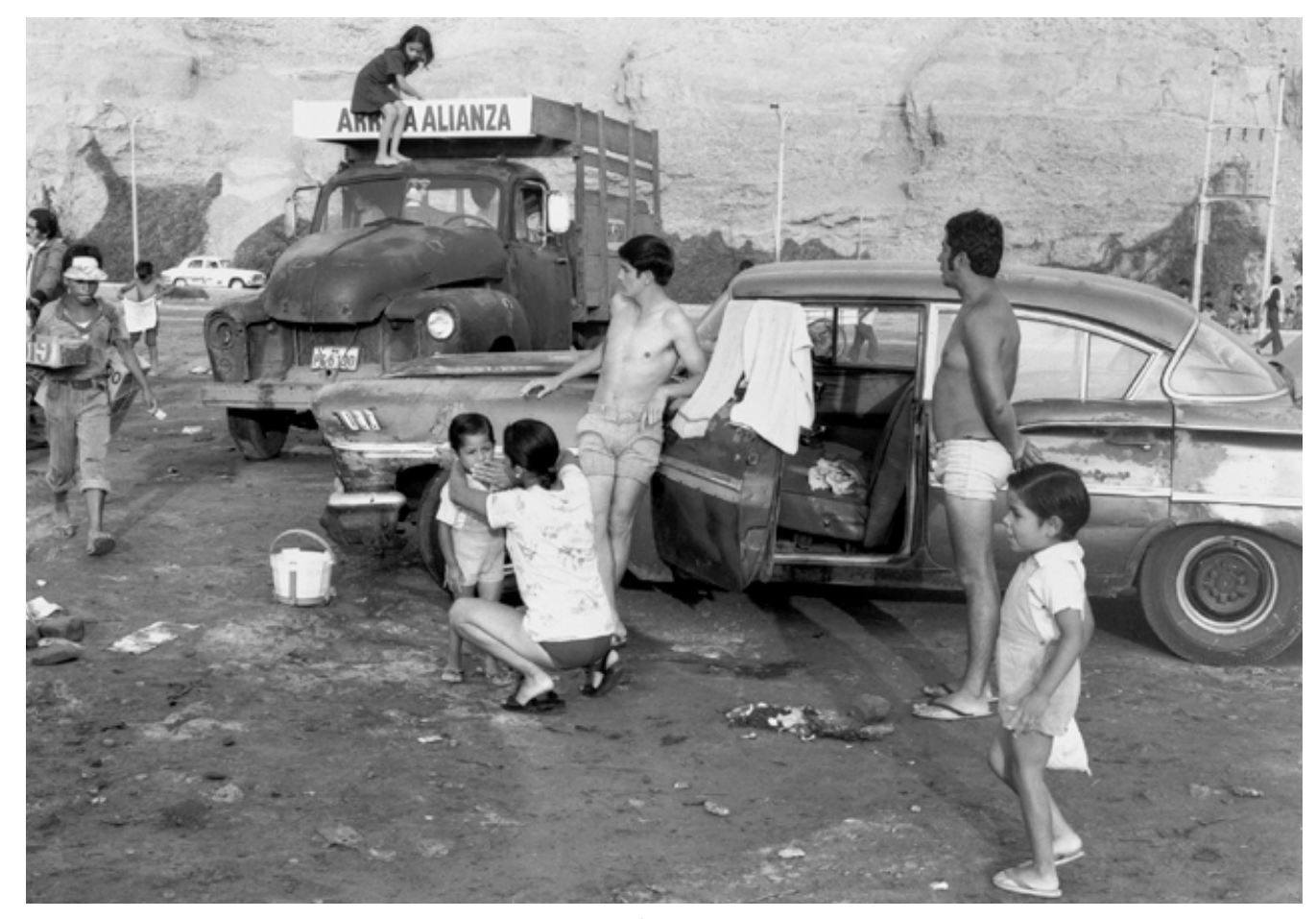

Serie "La costa". Playa Agua Dulce, 1986. Mariel Vidal.

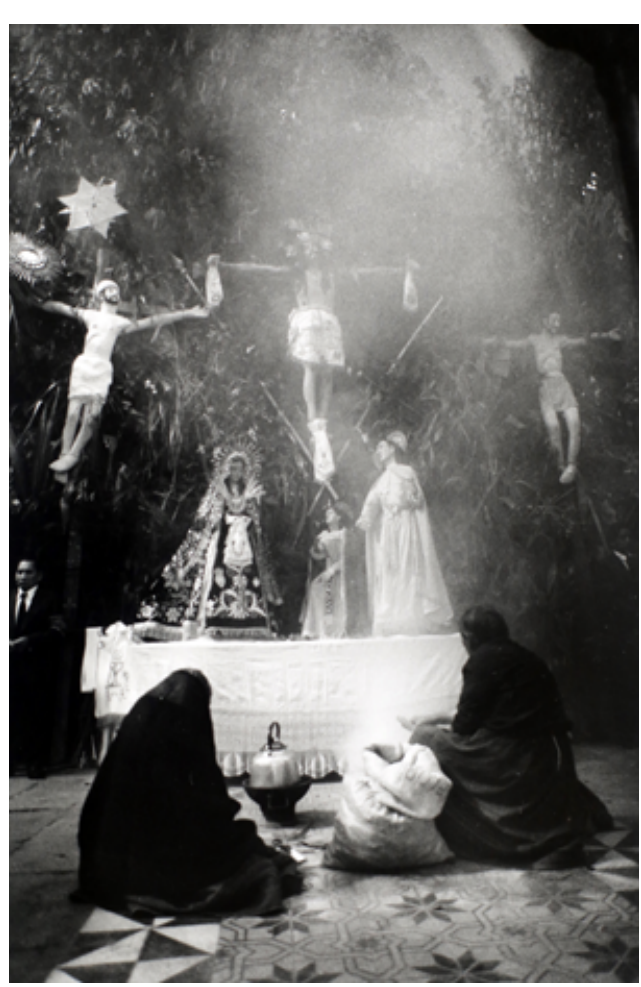

Serie "Viernes Santo". Huanta, Ayacucho, 1994. Nancy Chappell.

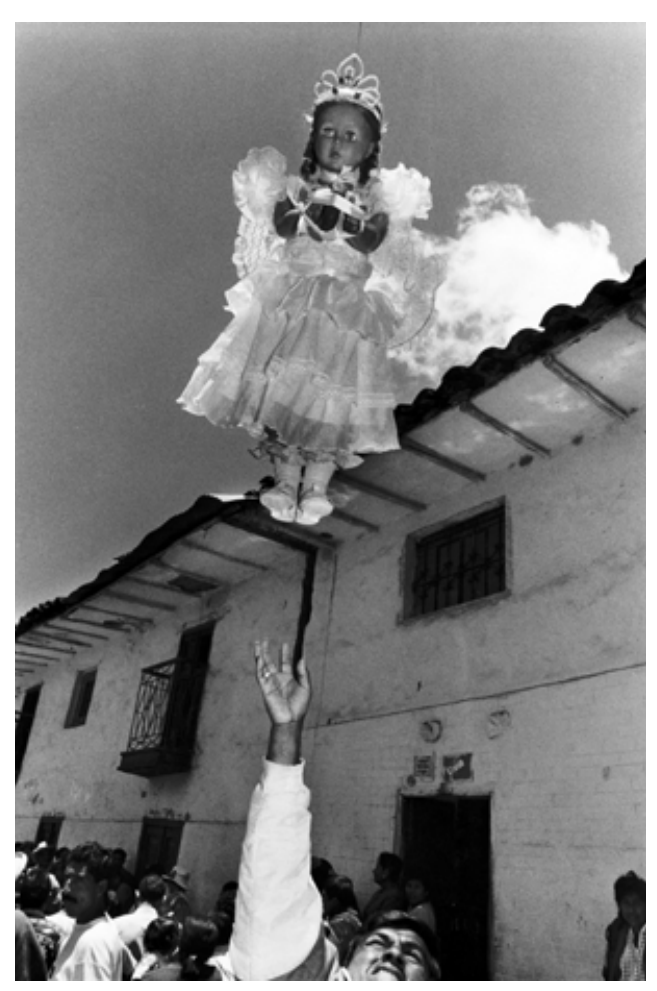

Serie "Rituales". Ayabaca, Piura, 1996. Mayu Mohanna. 


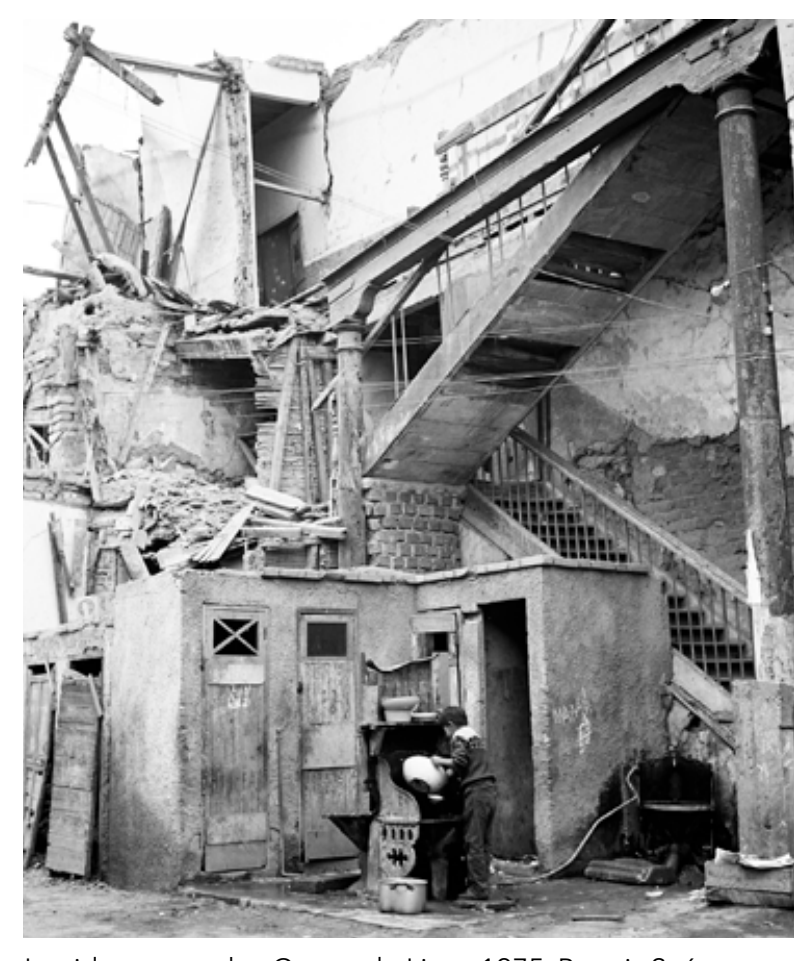

La vida en un solar. Centro de Lima, 1975. Beatriz Suárez.

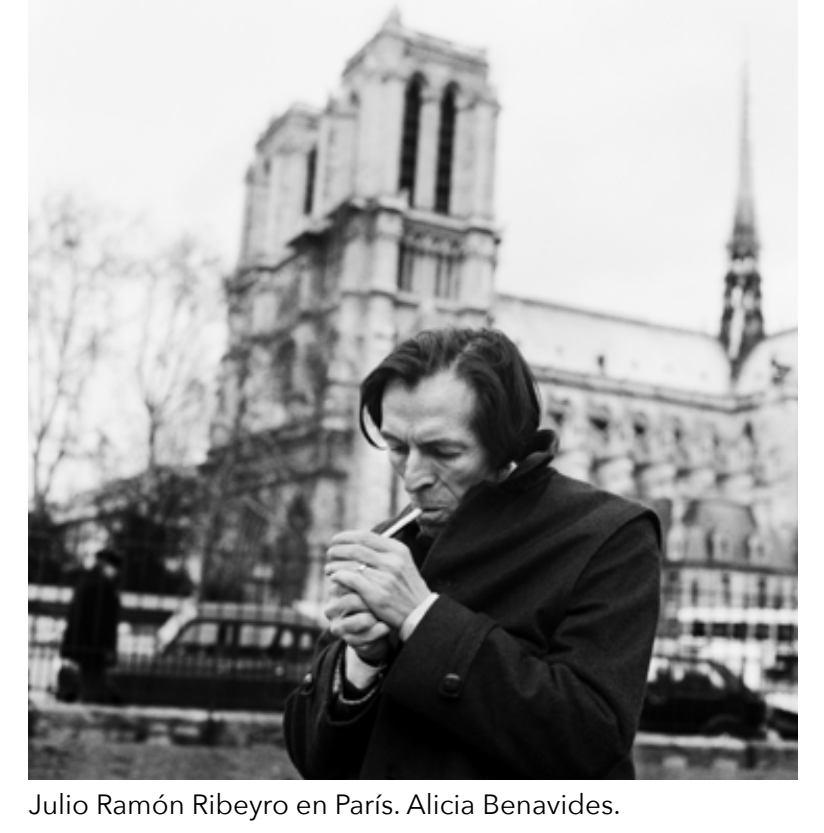

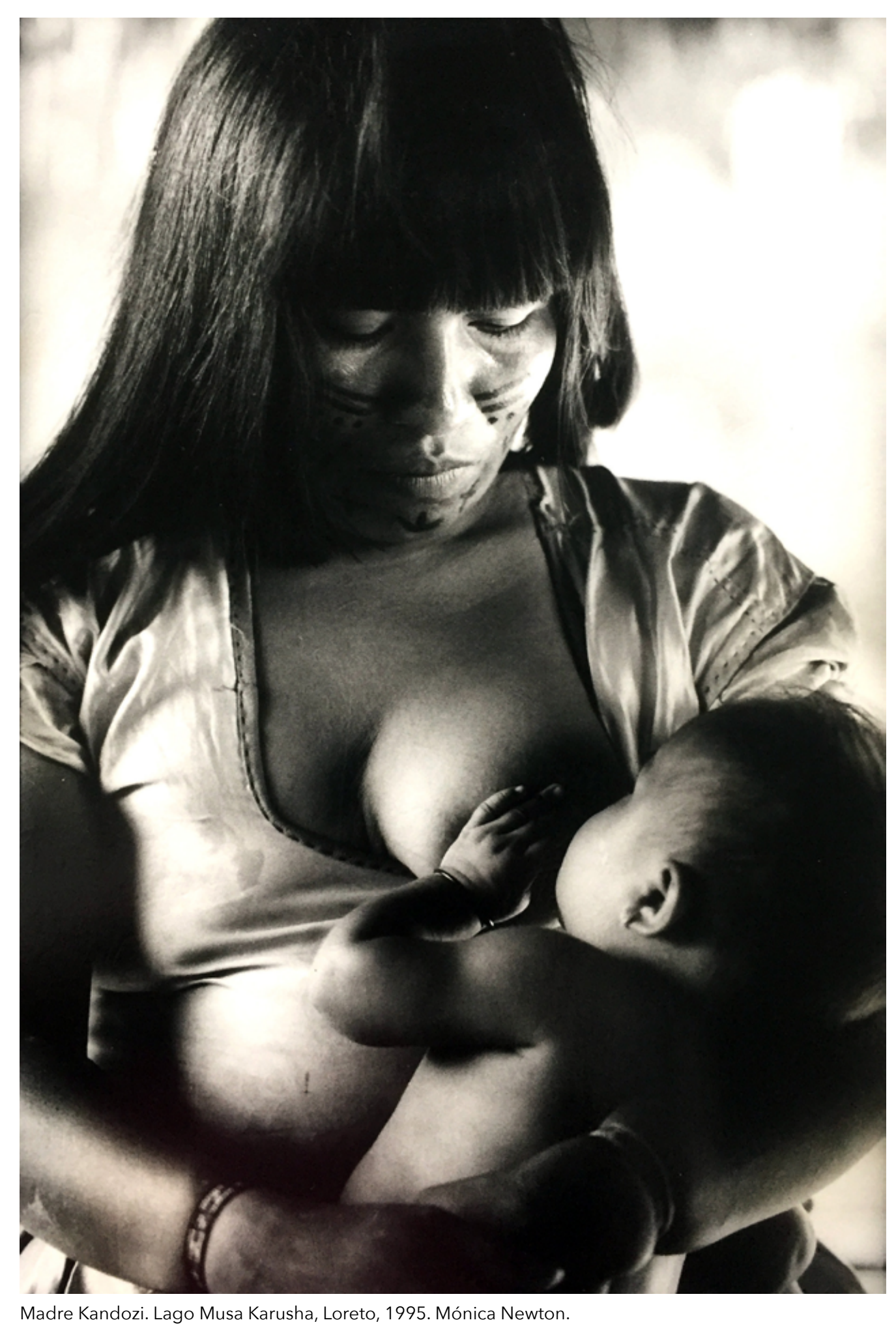

